\title{
Lymphocyte phenotyping in untreated children patients with chronic allergic asthma
}

\author{
Maiss Kasim Ibadi *
}

Date of acceptance $1 / 3 / 2010$

\begin{abstract}
This study aimed to isolate and phenotype lymphocytes in untreated children patients with chronic allergic asthma. To reach such aim the study involved (25) patients from children (17 male and 9 female) whom their ages where between (3-10) years, in addition to (15) apparently healthy children ( 9 male and 6 female) in the same ages involved as control group.

The data demonstrated that there was a significant increase in the mean percentages of T-lymphocytes $\left(\mathrm{CD}_{3}{ }^{+}\right.$cells) in the peripheral blood of patients $(66.75 \pm 0.29)^{* *}$, in comparison with control group (43.58 \pm 0.19$)$, a significant increase in the mean percentages of T-helper lymphocytes $\left(\mathrm{CD}_{4}{ }^{+}\right.$cells) in the peripheral blood of patients $(51.14 \pm 0.55)$, in comparison with control group $(39.17 \pm 0.23)$ and the mean percentages of B-lymphocytes $\left(\mathrm{CD}_{20}{ }^{+}\right.$cells) was also increased significantly in the peripheral blood of patients $(29.63 \pm 0.20)$ when it compared with the mean percentages of the same cells in control group (18.60土0.80).

Besides a significant decrease in the mean percentages of T-suppressor lymphocytes $\left(\mathrm{CD}{ }^{+}\right.$cells $)$in the peripheral blood of patients $(11.31 \pm 0.05)$, in comparison with control group (16.42 \pm 0.15$)$. Finally the results of this study showed a significant increase in the mean percentages of the ratio of $\left(\mathrm{CD}_{4}{ }^{+}\right.$cells $/ \mathrm{CD}^{+}$cells $)$in the peripheral blood of patients $(55.34 \pm 0.41)$, in comparison with control group (31.25 \pm 0.09$)$.
\end{abstract}

Key words: The mean percentage \pm standard error is used to describe the results

\section{Introduction}

Chronic allergic asthma is a common chronic inflammation condition of the lung airways whose cause is incompletely understood. It is a chronic disease because it mediated by $\mathrm{IgE}$ and it may be last for all life time Symptoms are cough, wheeze, chest tightness and shortness of breath often worse at night .

It has three characteristics:

- Airways inflammation may be accompanied by irreversible airflow limitation.

- Airway hyperresponsiveness to a wide range of stimuli.
- Inflammation of bronchi with eosinophils, T-lymphocytes and mast cells with associated plasma exudation, oedema, smooth muscle hypertrophy, mucus plugging and epithelial damage [1].

The pathogenesis of chronic allergic asthma is complex and it involves a number of cells, mediators, nerves and vascular leakage that can activated by several different mechanisms, of which exposure to allergens is the most important [2] .

* Science College for Women / Baghdad Universitv 


\section{Aim of the study}

This study amid to isolate and phenotype of lymphocytes in untreated children patients with chronic allergic asthma and compared them with control group.

\section{Study samples}

In this study 25 children asthmatic patients were enrolled. There ages ranged between $3-10$ years. They were from patients, who attended Child's Central Teaching Hospital in Baghdad in a period between September 2008 to January 2009. The diagnosis was based on the patient's medical history, physical examination and laboratory test results under supervision of specialists physicians. The patients were suffered from chronic allergic asthma with positive skin test response and positive IgE test to one or more of common aeroallergens. They were also had other allergic symptoms and had one or more from their families with one of the allergic diseases. This study involved also 15 apparently healthy children in the same ages as control group.

\section{Materials and methods:}

\section{Blood sample collection}

Blood samples $(4 \mathrm{ml})$ were collected by vein puncture using disposable syringe from all patients and control group, placed in a Heparin test tube in order to use for isolation and phenotyping of lymphocytes.

\section{Lymphocyte isolation \& phenotyping}

I. Lymphocyte isolation:

It was done by using density gradient sedimentation method [3], according to the following steps:

1. Four $\mathrm{ml}$ of fresh blood in a sterile Heparin test tube. The heparinized blood was diluted $1: 1$ (V/ V) with Phosphate
Buffer Saline (PBS) with gently mixed.

2. Four $\mathrm{ml}$ of lymphocytes separation medium (Lymphoprep) were dispended in a sterile glass centrifuge tube $(10 \mathrm{ml})$. Then $4 \mathrm{ml}$ of diluted blood was carefully layered on top of the lymphocytes separation medium.

3. The tubes were transferred to the cold centrifuge, centrifuged at $2000 \mathrm{rpm}$ for $30 \mathrm{~min}$. in $4^{\circ} \mathrm{C}$. After centrifugation, the lymphocytes will have formed a grey layer at the interface of the blood plasma and lymphocytes separation medium. With great care the supernatant blood plasma aspirated and discarded, therewith the aspiration of lymphocytes layer using a sterile Pasteur pipette was easier.

4. The lymphocytes were transferred into Can tubes and 5 $\mathrm{ml}$ of Hank's solution was added with gentle mixing. The suspension was centrifuged in cold centrifuge at $1000 \mathrm{rpm}$ for $10 \mathrm{~min}$. in $4^{\circ} \mathrm{C}$.

5. After centrifugation, supernatant was discarded and the pellet was re-suspended in 3 $\mathrm{ml}$ of Hank's solution. The suspension was centrifuged in cold centrifuge at $1000 \mathrm{rpm}$ for $10 \mathrm{~min}$. in $4^{\circ} \mathrm{C}$. The supernatant was discarded again and the pellet was re-suspended in $3 \mathrm{ml}$ of RPMI - 1640 media.

6. Ten $\mu \mathrm{l}$ of the cell suspension was placed on the hole in slide that specialized for immunofluorescent microscope, the slide was left in room temperature $23^{\circ} \mathrm{C}$ for 2 hours until it is completely dried. 
7. Ten $\mu \mathrm{l}$ of fixative solution was placed on every hole of the slide that specialized for immunofluorescent

microscope for $30 \mathrm{sec}$, the slide was covered by foil and kept in freezer at $-20^{\circ} \mathrm{C}$ until the time of use

8. To obtain viability test, three droplets of cell suspension were mixed with one droplet of trypan blue $1 \%$. A drop was placed on clean slide, covered with a cover slide and observed under light microscope. Hundred lymphocytes were counted. $95 \%$ or above, viability rate was considered acceptable.

II. Lymphocytes phenotyping:

The lymphocytes were phenotyped by using two sets of monoclonal antibodies specialized for two types of $\mathrm{CD}$ markers, $\mathrm{CD}_{3}$ that is characteristic to the surface of T-lymphocytes and $\mathrm{CD}_{20}$ that characteristic to the surface of B-lymphocytes. Two subsets of monoclonal antibodies specialized for two types of $\mathrm{CD}$ markers were used also, CD4 that is characteristic to the surface of T-helper lymphocytes and $\mathrm{CD} 8$ that is characteristic to the surface of T-suppresser lymphocytes.

Lymphocyte phenotyping was done by using fluorescence microscopy determination of $\left(\mathrm{CD}_{3}, \mathrm{CD}_{4}, \mathrm{CD} 8\right.$ and $\mathrm{CD}_{20}$ ) supplied by Serotec/ England, according to the following steps[4]:

1. The slides were get out from the freezer, the foil was removed and the slides were left in room temperature $23^{\circ} \mathrm{C}$ for $2 \mathrm{~min}$.

2. The slides were washed in a glass container that contains Phosphate Buffer Saline (PBS) for $5 \mathrm{~min}$. with gently moving.

3. The slides were taken out from the container, $10 \mu \mathrm{l}$ of each fluorescence microscopy determination $\left(\mathrm{CD}_{3}, \mathrm{CD}_{4}, \mathrm{CD} 8\right.$ and $\mathrm{CD}_{20}$ ) were added to the holes in immunofluorescent microscope slides.

4. The slides were placed in humidity chamber and transferred to incubator, left there for 2 hours at $37^{\circ} \mathrm{C}$. Ten $\mu \mathrm{l}$ of mounting media were added to each hole in the slides, cover slides were carefully added, then the slides were read under the fluorescent microscope.

5. Reading the microscope slide for each field, the lymphocytes number was counted under light microscope field and the number of fluorescent lymphocytes was counted under the converter fluorescent microscope field. The number of fluorescent lymphocytes was recorded. Observation continued until the number of lymphocytes observed under light microscope reached 100 , thereby the number of fluorescent lymphocytes represent the percentage of lymphocyte positive CDmarker that was tested.

\section{The statistical analysis}

Statistical analysis was performed by Statistical Package of Social Sciences (SPSS). The data analysis was done by using Analysis of Variance test (ANOVA) according to Complete Randomized Design (CRD).The significant differences between studied mean percentages were tested according to Duncan's multiple range test [5].

\section{Results \& discussion}

\section{T-lymphocytes}

The results demonstrated a significant increase $(P<0.01)$ in the mean percentages of T-lymphocytes $\left(\mathrm{CD}_{3}{ }^{+}\right.$cells $)$in peripheral blood of 
patients $(66.75 \pm 0.29)^{*}$, in comparison with control group $(43.58 \pm 0.19)$, (table. 1).

The increase of T-lymphocytes $\left(\mathrm{CD}_{3}{ }^{+}\right.$cells) in peripheral blood of patients in present study refers to the role of these cells in allergic inflammation especially in recognition phase. That begins when the professional antigen presenting cells (dendritic cells in the airways) direct T- lymphocytes development down the T-helper lymphocytes pathway, through the interaction between $\mathrm{CD}_{3}$ on T-lymphocytes and B7 on dendritic cells and their secretion of cytokines especially Interleukin-1 and Interleukin-12 [6].

\subsection{T-helper lymphocytes}

The results showed a significant increase $(\mathrm{P}<0.01)$ in the mean percentages of $\mathrm{T}$-helper lymphocytes $\left(\mathrm{CD}_{4}{ }^{+}\right.$cells) in peripheral blood of patients $(51.14 \pm 0.55)$, in comparison with control group $(39.17 \pm 0.23)$, (table. 1). The increase of $\mathrm{T}$-helper lymphocytes $\left(\mathrm{CD}_{4}^{+}\right.$cells) in peripheral blood of patients with chronic allergic asthma was parallel to the increase of T-lymphocytes $\left(\mathrm{CD}_{3}{ }^{+}\right.$cells), which reflex the importance of $\mathrm{T}$-helper lymphocytes among many cells participating directly in immune response.

* The mean percentage \pm standard error is used to describe the results

T-helper lymphocytes (Th) and relative levels $\left(\mathrm{Th}_{1}\right)$ and $\left(\mathrm{Th}_{2}\right)$ subsets play a key role in the regulation of type- I hypersensitivity response[7].

There are many studies assured the role of T-helper lymphocytes especially the subset $\left(\mathrm{Th}_{2}\right)$ which acts as essential active and stimulated cells in allergic inflammation, because it has the ability to differ allergens that enter the body which present by antigen presenting cells. The result of this reaction between $\mathrm{Th}_{2}$ and antigen presenting cells is the beginning of stimulatory signals which lead to the releasing and secretion of cytokines[8].

By the effect of Th2 products (Interleukin-4 (IL-4) and Interleukin13(IL-13)) these cells promote Blymphocytes to switch IgG synthesis and activate eosinophils differentiation and maturation [6]. Beside that Th2 produced also Interleukin-2 (IL-2) and interferon- $\gamma$ (IFN- $\gamma$ ). Interleukin-2 (IL-2) regards as an effective factor in maturation and differentiation of $\mathrm{B}$ lymphocytes while IFN- $\gamma$ effects in selection of Immunoglobulin [1].

These results agreed with one of previous studies which recorded the identification of T-lymphocytes $\left(\mathrm{CD}_{3}{ }^{+}\right.$ cells) in bronchial biopsies and bronchoalveolar fluid from chronic asthmatic individual [9]. One of the other studies suggested that immune activation in asthma is associated with migration of T-helper lymphocytes out of the airways into circulation[2].

\subsection{T-suppressor lymphocytes}

The result showed a statistically significant decrease $(\mathrm{P}<0.01)$ in the mean percentages of $\mathrm{T}$-suppressor lymphocytes $\left(\mathrm{CD}_{8}{ }^{+}\right.$cells) in peripheral blood of patients $(11.31 \pm 0.05)$, in comparison with control group (16.42 \pm 0.15 ), table (1)

This decrease occurred because of the migration of allergen specific $\mathrm{T}$ suppressor lymphocytes from the circulation to the lung after exposure to allergen, in order to inhibit $\operatorname{IgE}$ synthesis by B-lymphocytes in airways [6].

One of the previous studies investigated the mechanism of $\mathrm{T}$ suppressor lymphocytes mediated IgE suppression. This study reported that T-suppressor lymphocytes promote (Th1) immunity and inhibit $\operatorname{IgE}$ responses, because (Th1) demonstrate a negative regulatory effect on IgE 
response particularly through its ability to antagonize the induction of (Thi) type response [10].

\section{B-lymphocytes}

The results demonstrated that the mean percentages of B-lymphocytes $\left(\mathrm{CD}_{20}{ }^{+}\right.$cells) was increased significantly $(\mathrm{P}<0.01)$ in peripheral blood of patients $(29.63 \pm 0.20)$ when it compared with the mean percentages of the same cells in peripheral blood of

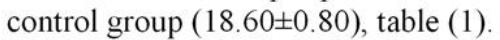

This result was in harmony with the result of previous study [11] which refers to the increase of B-lymphocytes in asthmatic patient. The percentage of B-lymphocytes increased in peripheral blood of patients of present study, because of the role of (IL-4) which was identified as a B-cell growth factor (BGF) and it is known also as a B-cell stimulating factor-1(BSF). That it leads to the typical stimulation for these cells to antigens and enhancing $\operatorname{IgE}$ synthesis. On the other hand it has a key role in stimulating B-lymphocytes in isotype switching from $\operatorname{IgM}$ to $\mathrm{IgE}$ [7].

Besides that there is the role of Interleukin-6 (IL-6) that produced from activated T-lymphocytes, monocytes and bone marrow stromal cells such as fibroblast, endothelial cells and macrophage, these cells are involved in inflammatory response. (IL-6) is a vital cytokine involved in B-lymphocytes regulation and maturation in addition to promote Immunoglobulin production [1]. This cytokine act as a conversion factor leads and regulates (IL-4) dependent synthesis of $\mathrm{IgE}$, as well as (IL-6) provide a late amplification signal in isotype switching from IgM to $\operatorname{IgE}[12]$.

2. The ratio of T-helper lymphocytes/T-suppressor

lymphocytes $\left(\mathrm{CD}_{+}^{+}\right.$cells $/ \mathrm{CDs}^{+}$cells)

The results in certain study improved a significant increase $(\mathrm{P}<0.01)$ in the mean percentages of the ratio of $\left(\mathrm{CD}_{4}{ }^{+}\right.$ cells $/ \mathrm{CD}^{+}$cells) in peripheral blood of patients $(55.34 \pm 0.41)$, in comparison with control group (31.25 \pm 0.09$)$, (table. 1).

This result was in agreement with the study of [10] which used $\left(\mathrm{CD}_{4}{ }^{+}\right.$ cells $/ \mathrm{CDs}^{+}$cells) ratio as a test to differentiate between patients with allergic asthma and non- allergic asthma. On other hand this result was in harmony with the study of [11] that assured on the importance of $\left(\mathrm{CD}_{4}{ }^{+}\right.$ cells $/ \mathrm{CD}^{+}$cells) ratio and regarded its increase in asthmatic patients more important than the increase in total number of T-helper lymphocytes.

The current study suggests that $\left(\mathrm{CD}_{4}{ }^{+}\right.$cells $/ \mathrm{CDs}^{+}$cells) ratio can be regarded as an indicator for chronic allergic asthma and whenever it increase, that will refer to an increase in chronicity of allergic asthma depending on the constrant effect of airways inflammation on both T-helper lymphocytes and T-suppressor lymphocytes, because it leads to proliferation of T-helper lymphocytes in peripheral blood enhancing $\mathrm{IgE}$ synthesis and isotype switching from $\operatorname{IgM}$ to $\operatorname{IgE}$. As well as it leads to depletion of T-suppressor lymphocytes from peripheral blood in order to migration to the airways to inhibit $\operatorname{IgE}$ synthesis by B-lymphocytes [1]. 
Table (1) The mean percentage of lymphocytes that carrying $\mathrm{CD}$ markers $\left(\mathrm{CD}_{3}\right.$, $\mathrm{CD}_{4}, \mathrm{CD}$ and $\mathrm{CD}_{20}$ ) in the peripheral blood of patients group and control group

\begin{tabular}{|c|c|c|c|c|c|c|c|c|c|c|}
\hline \multirow{2}{*}{ Group type } & \multirow{2}{*}{ Number } & \multicolumn{6}{|c|}{ The mean percentages of lymphocytes that carrying CD markers (CD3, CD4, CD8 and CD20) in the peripheral bloot of patients group and } \\
control group
\end{tabular}

The similar letters mean there are no significant differences and the different letters mean there are significant differences at probability $(P<0.01)$.

\section{References:}

1. Kumar, P. \& Clark, M. 2003. Kumar and Clark Clinical Medicine. W.B. Saunders, 5th Ed., London. UK. PP: $213,407,874-878$.

2. Helgate, S. T. 2008. Asthma and allergy. Quar. J. Med. 97: 171-184.

3. Boyum, A.1968. Isolation of mononuclear cells and granulocytes from human blood, Clin. Lab. Invest., 21 (Suppl. 97): 77-89.

4. Marion, D.H. and Catherine, M.K. 1998. A Manual of Cytotechnology and Cytopreparatory Techniques. Blackwell Scientific Publications. U.K. PP: 335, 348.

5. Duncan, D.B. 1955. Multiple range F-test. Biometrics., 11(1): 1-42.

6. Chapel, H . ;Haeney, M. \& Misbah, S. 2006. Essential of Clinical Immunology. Blackwell Scientific Publications, 5th Ed., U.K. PP: 8587

7. Gelfand, E. W. 2000. Cytokines in allergic diseases: Will the real culprit please stand up?. American Academy of Allergy, Asthma and
Immunology. 56 $6^{\text {th }}$ Annual meeting. File://A/TMP97479600htm.

8. PlattsMills, T. 2002. Hypersensitivity Type 1. In: Roitt, I.; Brostoff, J. \& Male, D. (eds). Immunology Mospy publishing, $6^{\text {th }}$ Ed., Spain. PP:324-328.

9. Robinson, D.; Hamid, Q.; Ying, S. et al. 1992. Predominant TH2 like broncoaveolar T-lymphocyte population in asthma, N. Engl. J. Med. 362: 298-304.

10. Al-Ta'ie, M.A. 2002. Immunological study on allergic asthma patients. PHD. Thesis. Coll. Sci Univ. AL-Mustansiryah.

11. Lee, S. Y.; Kim, S. J.; Kwon, S. S. et al. 2002. Distribution and cytokines production of $\mathrm{CD}^{+}$and $\mathrm{CD}^{+}$T-lymphocyte subsets in patients with asthma attacks, Ann. Allergy-Asthma Immunol. 86:659664.

12. Roitt, I.M. \& Delves, P.J. 2001. Roitt's Essential Immunology., Blackwell Scientific Publications, 10th Ed., U.K. PP: 55, 179, 185. 
توصيف الخلايا اللمفاوية عند الأطفال غير المعالجين المصابين بالربو الارجي

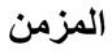

* كلية العلوم للبنات / جامعة بغداد

كلمات مفتاحية: توصيف الذلايا اللمفاوية, الربو الارجي المزمن, الذلايا التائية, الذلايا البائية.

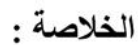

هدفت هذه الدراسة إلى عزل وتوصيف الخلايا اللمفاوية عند الأطفال غير المعالجين المصابين بالربو الارجي الإبي

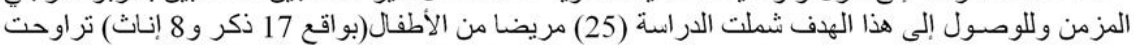

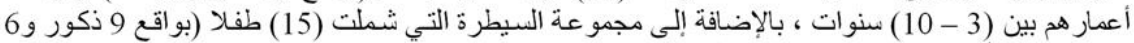

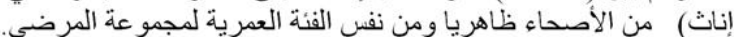

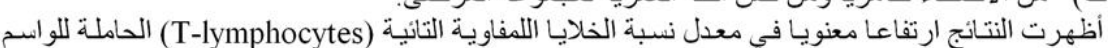

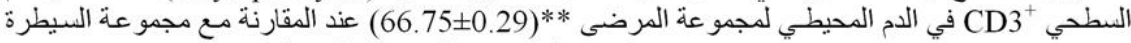

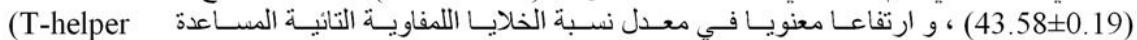

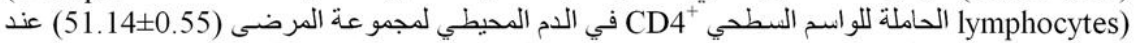
المقارنة مع مجو عة السبطرة (39.23.17.0.23)، وارتفع معدل نسبة الخلايا اللمفاوية البائية (B-lymphocytes)

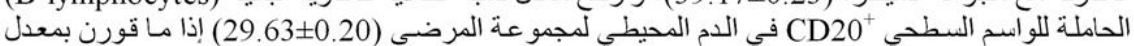

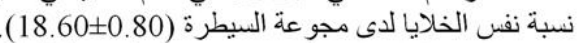

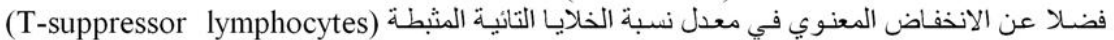

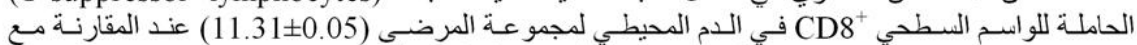

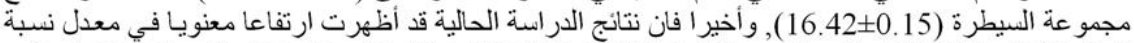
الخلايا اللمفاوية التائية المساعدة إلى نسبة الخلايا اللمفاوية التنائية المثبطة (CD4

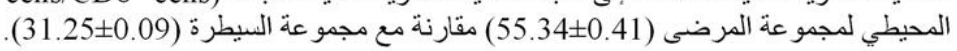

